Western North American Naturalist 67(4), (C) 2007, pp. 605-608

\title{
OBSERVATIONS ON AN ASSOCIATION BETWEEN THE WEEVIL SCAPHOMORPHUS TRIVITTATUS (SAY) AND TWO ASTRAGALUS SPECIES ON SELENIUM-RICH SOILS IN CARBON COUNTY, UTAH
}

\author{
Gary R. Hooper ${ }^{1,3}$, and Boyd F. Holdaway ${ }^{2,4}$
}

\begin{abstract}
The weevil Scaphomorphus trivittatus (Say) was found in close association with Astragalus praelongus var. elliseae (Rydb.) and Astragalus asclepiadoides (Jones) in selenium-containing soils in Carbon County, Utah. The weevils fed on roots of the Astragalus species and formed soil cocoons, which were attached to the tap roots. The weevils pupated and developed into adults in these cocoons over the fall and winter and then emerged in the spring. The plants and soil cocoons contained highly elevated levels of selenium compared to the soils. The weevils, in contrast, differed little from the soils in selenium content.
\end{abstract}

Key words: Scaphomorphus, Astragalus, soil cocoons, selenium.

Several plant species take up and accumulate selenium from soils. In the 1970s we initiated a study of the possible involvement of bacterial nodules and/or fungal mycorrhizae on Astragalus species, which do accumulate selenium. During this study we became aware of an association between a weevil, Scaphomorphus trivittatus (Say), and the legumes Astragalus asclepiadoides (Jones) (milkweed vetch) and A. praelongus var. elliseae (Rydb) (Ellis stinking milkvetch). We made observations on this weevil-plant association over a number of years between the late 1970s and the present.

We selected for our study an area of alluvial, sandy soils about $19 \mathrm{~km}$ south of Wellington, Carbon County, Utah, along State Highway 9. The soils in this area are high in selenium and both A. asclepiadoides and A. praelongus var. elliseae grow there.

In the process of digging to expose the roots of the plants, we discovered that many individuals of both species had soil "cocoons" firmly attached to the taproot-usually from 15 to $25 \mathrm{~cm}$ below the soil surface (Fig. 1). The cocoons were usually $\sim 2.5-3.5 \mathrm{~cm}$ long and $\sim 1.0-1.5 \mathrm{~cm}$ wide and were composed of hard, compacted silt and clay. At the cocoon's point of attachment to the root, plant fibers were incorporated into the cocoon matrix. The roots often had scars, presumably caused by feeding activities of insect larvae (Figs. 1, 3).

In several years cocoons were observed from spring and early summer into the winter. They contained larvae and/or adults of a large weevil. The insects ranged from $11 \mathrm{~mm}$ to $15 \mathrm{~mm}$ long and were beige to off-white in color with prominent reddish brown stripes (Fig. 4). Some larvae and adults were dead and appeared to be infected with unknown fungi.

Insects were collected and deposited in the Monte L. Bean Life Science Museum, Brigham Young University (Provo, UT), and in 1996 some were sent to Dr. Wayne Clark of Auburn University (Auburn, AL) for identification. At that time he identified the insect as Cleonidius trivittatus (Say). Since then this species has been grouped with other related weevils and is now called Scaphomorphus trivittatus (Say) (Anderson 1988, 2002).

Occurrence of this weevil and related species on Astragalus and other legumes is well known (Anderson 1988), and collections of similar weevils at Utah Sate University also list legumes as host plants (personal observation, October 2006).

Because the weevils appeared to feed on only the 2 Astragalus species being studied at our site, we included these species in our analysis of selenium uptake and accumulation in plant tissues.

\footnotetext{
${ }^{1}$ Department of Botany and Range Science, Brigham Young University, Provo, UT 84602.

${ }^{2}$ Department of Biology, Ricks College [BYU-Idaho], Rexburg, ID 83460.

3Present address: 2008 Spring Oaks, Springville, UT 84663. E-mail: gkhooper@msn.com

${ }^{4}$ Present address: 1050 South 2nd East, Rexburg, ID 83440.
} 

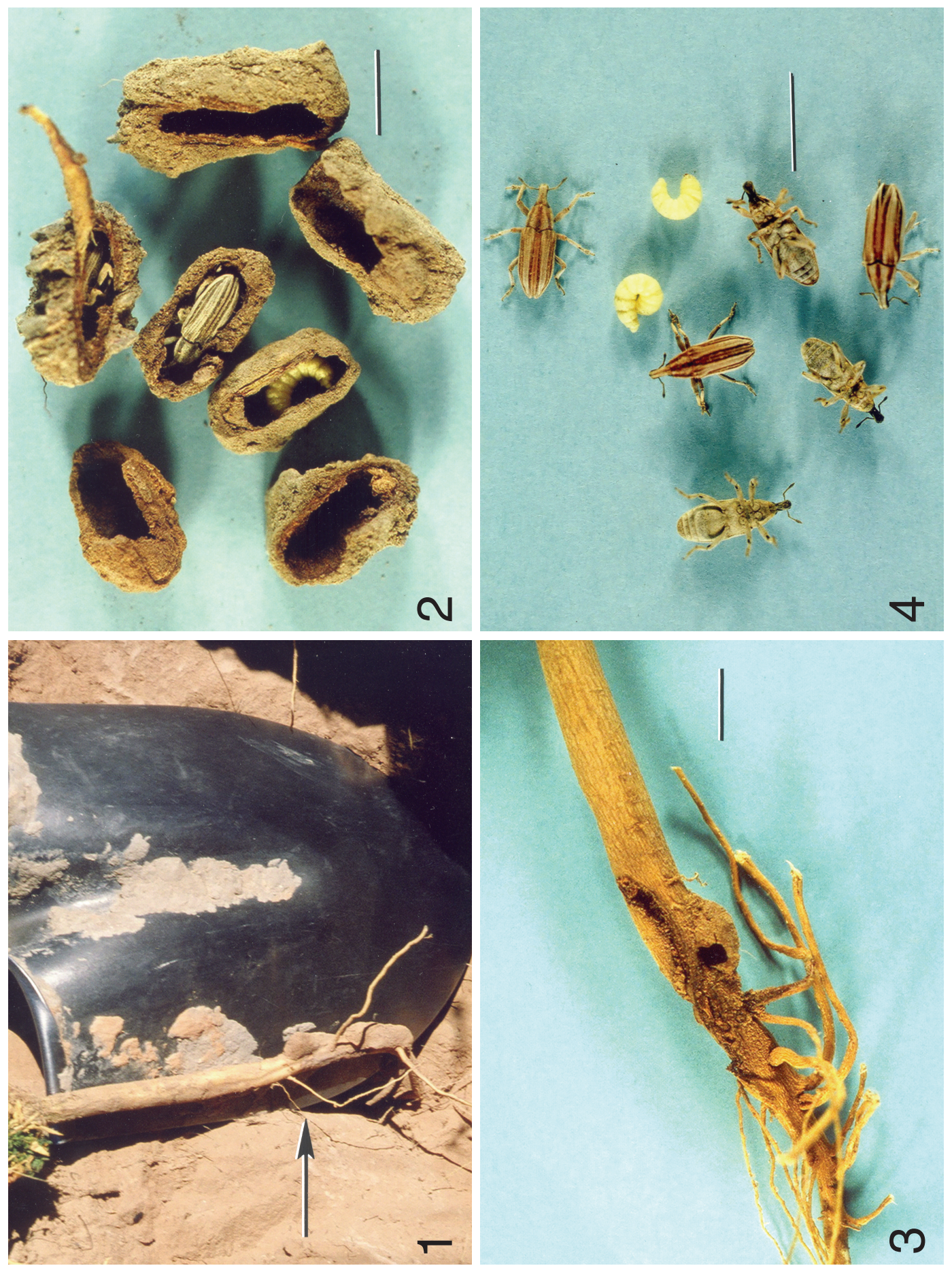

Figs. 1-4. 1, soil cocoons containing Scaphomorphus trivittatus (Say) on roots of Astragalus species. Cocoons occur near the tip of the root shown (arrow); 2, detached soil cocoons containing larvae and adults of Scaphomorphus trivittatus (Say). Note plant root fragment still attached to 1 cocoon. Scale bar equals $1 \mathrm{~cm}$; 3, Astragalus species root showing feeding scars and a remnant of a soil cocoon. Scale bar equals $1 \mathrm{~cm} ; 4$, adults and larvae of Scaphomorphus trivittatus (Say). Scale bar equals $1 \mathrm{~cm}$. 
TABLE 1. Selenium (ppm) in soil, plants, insects, and cocoons.

\begin{tabular}{lcccc}
\hline Sample month and year & Soil & Plants $^{\mathrm{a}}$ & Insects $^{\mathrm{b}}$ & Cocoons $^{\text {To }}$ \\
\hline November 1996 & 0.6 & 51.4 & 2.9 & 36.2 \\
September 1997 & 0.3 & 25.0 & 2.2 & 22.0 \\
\hline
\end{tabular}

Roots and stems (combined) of Astragalus asclepiadoides and A. praelongus var. elliseae

${ }^{b}$ Larvae and adults (combined) of Scaphomorphus trivittatus

Selenium is known to accumulate in a number of plants, bacteria, fungi, and invertebrates (including insects; Ohlendorf and Santolo 1994). Although the presence of selenium in plant tissues can add to the toxicity of the plants towards animals, little is known about adverse effects of selenium on plants or insects.

We assayed for selenium content using an adaptation of a method described in a PerkinElmer analytical instrument document (PerkinElmer 1992). The 2 Astragalus species, as well as the insect cocoons, had much higher levels of selenium than the soil. The larvae and adult weevils, however, had only slightly elevated levels of selenium over the soil (Table 1).

Our observations suggest a life cycle for $S$. trivittatus that is typical of those reported for related weevils. Adults emerge from the soil in spring and lay eggs on the host plant. Presumably, newly hatched larvae work their way to the roots and feed there. We did not observe any larvae on aboveground plant tissues at any time. The larvae feed on roots and build a protective soil tube or "cocoon" attached firmly to the root over the feeding site. Transformation of the larvae into pupae and adults occurs within this cocoon during early summer.

Similar protective structures are reported as "sand tubes" constructed by Cleonidius poricollis (Mannerheim) on Descurainia pinnata (Walt.) Britton (Tansy mustard) in West Texas (O'Brien and Marshall 1987). These authors suggest that the "sand tubes" provide protection for the feeding larvae and allow space for pupation in roots that are too small in diameter to allow the insect to be fully enclosed by plant tissues. They further suggest that this "sand tube" phenomenon may be a ". . . widespread means by which Cleonidius or other weevil larvae functionally increase the diameter of the stem or root on which they are feeding ..." An earlier paper (Isart 1972) reported on Cleonus mendicus (Gyll.) and its host plant Beta vulgaris (L.) (sugar beet) in several Mediterranean countries. The insect larvae involved fed only upon the root of the plant and con- structed galleries fully within the root as well as "cocoon terroso," or soil cocoons, on the root surface. The soil chambers or cocoons illustrated by Isart (1972:203-204, fig. 3) are very similar to those we observed on Astragalus.

It is interesting that Cleonus mendicus larvae feed well within the large sugar beet root but still construct external cocoons of soil for pupation, whereas weevils feeding upon smaller roots, such as D. pinnata or Astragalus species, do not seem to burrow deeply into their host root tissue during feeding but do also make soil cocoons. Perhaps the construction of soil cocoons is not related to the size of host root, but is instead a common phenomenon of these weevils.

The accumulation of selenium within our Astragalus species is marked (see Table 1) and is considered 1 of the contributing factors in toxicity towards herbivores that feed upon such plants (Mayland 1994). However, we have found no mention of damage to the host plant itself from the selenium. In contrast to the high accumulation of selenium in plant tissues, weevils feeding upon the plant roots did not accumulate selenium in high amounts. This suggests that a mechanism exists to exclude or excrete the toxic chemical. The soil cocoons, presumably built using insect saliva, were high in selenium, which reflects the selenium-rich plant tissues being fed upon by the weevil.

Over a period of more than 20 years, we did not observe any effects of selenium upon either the plant or insect populations studied. Plants and insects appeared normal in size and reproduction; however, heavy grazing and trampling of plants by cattle on the study site have reduced the populations of Astragalus to a few colonies of small plants. Insect populations also have been greatly reduced in recent years at this site.

We thank Stanley L. Welsh of the Monte L. Bean Life Science Museum, Brigham Young University, for his assistance in locating Astragalus populations and in identifying the plant 
species involved. We also appreciate the efforts of Wayne Clark of Auburn University, and Richard W. Baumann and Shawn Clark of the Monte L. Bean Life Science Museum, Brigham Young University, in identification of this weevil. We also thank David Tingey of the Geology Department, Brigham Young University, for assistance with the selenium analysis.

\section{Literature Cited}

Anderson, R.S. 1988. Systematics, phylogeny and biogeography of New World weevils of the tribe Cleonini (Coleoptera: Curculionidae). Quaestiones Entomologicae 23:431-709.

.2002. Family 131. Curculionidae. Pages 722-815 in R.H. Arnett, Jr., M.C. Thomas, P.E. Skelley, and J.H. Frank, editors, American beetles. Volume 2. Polyphaga: Scarabaeoidea through Curculionidae. CRC Press, Boca Raton, FL.
ISART, J. 1972. Observaciones bioecologicas sobre Cleonus mendicus (Gyllanhal, 1834). Graellsia 28:177-204.

MaYLand, H.F. 1994. Selenium in plant and animal nutrition. Pages 29-45 in W.T. Frankenberger, Jr., and S. Benson, editors, Selenium in the environment. Marcel Dekker, Inc., New York.

O’Brien, C.W., AND G.B. Marshall. 1987. Unusual larvae "sand tube" construction in the weevil genus Cleonidius in West Texas. Southwestern Entomologist 12: 357-360.

Ohlendorf, H.M., and G.M. Santolo. 1994. Kesterson reservoir-past, present, and future: an ecological risk assessment. Pages 69-117 in W.T. Frankenberger, Jr., and S. Benson, editors, Selenium in the environment. Marcel Dekker, Inc., New York.

PerkinElmer. 1992. The THGA graphite furnace: techniques and recommended conditions. Pages 7-51 in PerkinElmer publication B3210, June 1992.

Received 31 August 2006 Accepted 12 January 2007 